\title{
Design of a Modular, High Step-Up Ratio DC-DC Converter for HVDC Applications Integrating Offshore Wind Power
}

\author{
Yihua Hu, Senior Member, IEEE, Rong Zeng, Student Member, IEEE, Wenping Cao, Senior
} Member, IEEE, Jiangfeng Zhang, Stephen J. Finney

\begin{abstract}
High power and high voltage gain DC-DC converters are key to high-voltage DC (HVDC) power transmission for offshore wind power. This paper presents an isolated ultra-high step-up DC-DC converter in matrix transformer configuration. A flyback-forward converter is adopted as the power cell and the secondary side matrix connection is introduced to increase the power level and to improve fault tolerance. Because of the modular structure of the converter, the stress on the switching devices is decreased and so is the transformer size. The proposed topology can be operated in column interleaved modes, row interleaved modes and hybrid working modes in order to deal with the varying energy from the wind farm. Furthermore, fault tolerant operation is also realized in several fault scenarios. A 400-W DC-DC converter with four cells is developed and experimentally tested to validate the proposed technique, which can be applied to high-power high-voltage DC power transmission.
\end{abstract}

Index Terms-DC-DC converter, high step-up, HVDC, matrix transformer.

\section{INTRODUCTION}

$\mathrm{P}$ OWER transmission is critically important for offshore wind farms in order to deliver bulky electrical power to the onshore grid over long distances [1]-[9]. Compared to the high-voltage alternating current (HVAC) transmission systems, high-voltage direct current (HVDC) transmission systems have a lower cable loss and are gaining in popularity in the large-scale offshore wind farms [10]-[13]. Because wind power is a unidirectional power source by its nature, a unidirectional DC-DC converter can be employed to connect the wind farm with the HVDC terminal.

Currently, many converter topologies are developed. One of the popular structures for offshore HVDC is the modular multilevel converter (MMC), in which high voltage is achieved by a medium-frequency high turns ratio transformer and high power by increasing the number of cells. The voltage stress on switching devices can be decreased by using a decentralized

Manuscript received May 4, 2015; revised July 24, 2015, September 21, 2015 and October 26, 2015; accepted November 7, 2015.

Copyright (c) 2015 IEEE. Personal use of this material is permitted. However, permission to use this material for any other purposes must be obtained from the IEEE by sending a request to pubs-permissions@ieee.org.

Y. H. Hu, R. Zeng, J. F. Zhang, and S. Finney are with the Department of Electronic and Electrical Engineering, University of Strathclyde, Glasgow G1 1XW, UK. (email: yihua.hu@strath.ac.uk; rong.zeng@strath.ac.uk; jiangfeng.zhang@strath.ac.uk; stephen.finney@strath.ac.uk )

W. P. Cao is with Massachusetts Institute of Technology, Cambridge, MA 02139, USA (email: wencao@mit.edu) structure [14]-[19]. However, such a transformer tends to be bulky and needs to process the full input power. Paper [19] combines an MMC with an alternate arm converter (AAC) to form a high-frequency DC-DC converter, which can decrease the transformer size. Nonetheless, the transformer still needs to handle the full power. On its secondary side, the AAC also requires a series-connected switch in each arm, giving rise to the converter complexity.

Alternatively, dual-active bridge converters are another topology commonly used for high-voltage high-power applications [20]. However, their secondary sides can only be connected in series so that their power level is limited. Paper [21] employs thyristors as the switching devices and develops a DC/DC converter for offshore HVDC applications. But the voltage step-up ratio is relatively low. Papers [22][23] propose multilevel converters using half-bridge and full-bridge cells. Although their input and output can share a common ground, these topologies do not provide electrical isolation. Paper [24] presents a resonant switched-capacitor topology with soft switching for various HVDC systems. However, the achievable conversion ratio is generally too low to meet the voltage stepup requirements. Paper [25] develops a multi-phase resonant DC-DC topology to step up the voltage level from low to medium voltage. A new topology to achieve a high conversion gain is reported in [26], based on the modular non-isolated DCDC converter. But this converter cannot provide electrical isolation. Paper [27] presents a resonant circuit for HVDC applications with soft switching while the topology is not a modular structure. Ladder structure converters are reported in paper [28]. By using the modular structure, the voltage stress on switching devices is decreased. The topologies in [14], [16], [17], [20], [23] are all bi-directional power conversion while the power flow is typically uni-directional for wind power systems. As a result, this paper develops a DC-DC converter for unidirectional power flow to transfer wind power from the wind farm to the HVDC terminal.

\section{Proposed ScAlABLE TOPOLOGY}

The proposed topology is shown in Fig. 1, which is composed of modular cells. Fig. 1(a) shows the topology of a cell. On its primary side, the cell includes two coupled inductors, two half-bridge modules and two clamp capacitors. On its secondary side, the two coupled inductors in the cell are in reverse series connection. $S_{1} \sim S_{2}$ are the main switching devices; $S_{c l} \sim S_{c 2}$ are the active clamping switching devices; $C_{c 1}$ and $C_{c 2}$ are the clamp capacitors. $L_{1} \sim L_{2}$ are the coupled inductors, the coupling terminals are remarked with "*”, and 


\section{IEEE TRANSACTIONS ON INDUSTRIAL ELECTRONICS}

"O". The primary and secondary winding turns of coupled inductors are $n_{1}$ and $n_{2}$, respectively. The leakage inductances are marked as $L_{L K 1}-L_{L K 2}$ for the coupled inductors $L_{1}-L_{2}$, respectively. Fig. 1(b) illustrates the proposed topology, where $S_{3} \sim S_{4}$ are the main switching devices; $S_{c 3} \sim S_{c 4}$ are the active clamping switching devices; $C_{c 3}$ and $C_{c 4}$ are the clamp capacitors; $L_{3} \sim L_{4}$ are the coupled inductors, and the coupling terminals are remarked with "ם", and "I". $L_{L K 3}$ and $L_{L K 4}$ are their leakage inductances. In Fig. 1(b), the primary sides of all cells are paralleled with the input source $V_{i n}$, and the secondary sides of all cells are connected in a matrix form. $D_{01}, D_{02} \ldots$ are the rectifier diodes. $R$ is the load resistance, and $C_{\text {out }}$ is the output capacitor. On the secondary side, an $s \times p$ matrix transformer is formed, where $s$ is the row number and $p$ is the column number. In the case of silicon carbide $(\mathrm{SiC})$ switches, high voltage high current devices are now commercially available such as QJD1210011_14 (1200 V/100 A). Higher voltage devices such as $10 \mathrm{kV} \mathrm{SiC}$ are becoming available [29]. Owing to the matrix structure on the secondary side, expanding the row number and column number can increase the power level and voltage step-up ratio, respectively. This makes the proposed topology flexible and scalable.
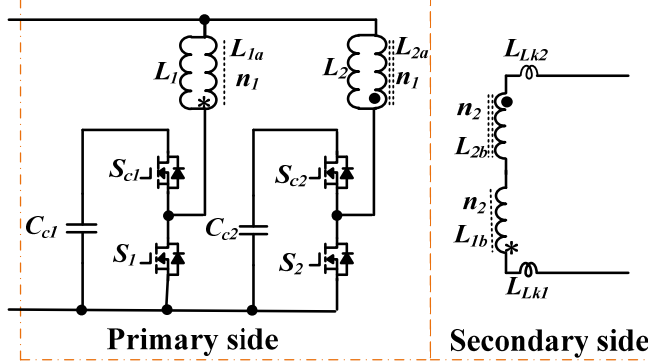

(a) Basic cell structure

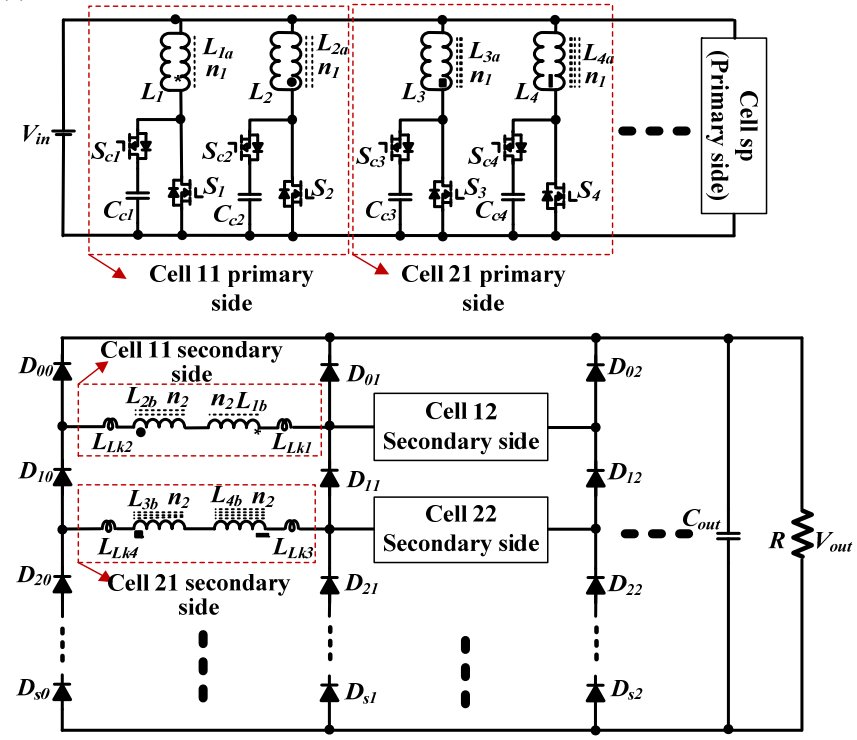

(b) Structure of the converter

Fig. 1 Proposed modular DC-DC converter.

A $2 \times 2$ topology is first developed to illustrate the working principle of the proposed topology, as shown in Fig. 2. For a single cell, typical waveforms are presented in Fig. 3 where the drive signals of main switching devices and clamp switching devices are complementary; and the duty ratio is fixed at 0.5 . In the intervals $\left[t_{1}, t_{2}\right]$ and $\left[t_{3}, t_{4}\right]$, soft switching of main switching devices and active clamp switching devices can be achieved due to the active clamp structure on the primary side of each cell [30]. There are four basic working stages for the single cell topology, as presented in Fig. 3 and explained in detail as follows.

Stage $1\left[t_{0}, t_{1}\right]$ : at $t_{0}$, main switch $S_{1}$ is turned on while $S_{2}$ is turned off. The clamping switch $S_{c l}$ is off and the clamping switch $S_{c 2}$ is on. $L_{1}$ works in forward mode and $L_{2}$ in flyback mode.

Stage $2\left[t_{1}, t_{2}\right]$ : at $t_{1}, S_{1}$ receives a turn-off gate signal, increasing its drain-source voltage in an approximately linear way of the main switch. Due to a low parasitic capacitance and a large current in the primary-side circuit of the coupled inductor, this period is short. At $t_{1}, S_{c 2}$ receives a turn-off gate signal. At this stage, the switching devices can achieve soft switching.

Stage $3\left[t_{2}, t_{3}\right]$ : at $t_{2}, S_{2}, S_{c l}$ receive a turn-on signal. $L_{2}$ works in forward mode and $L_{l}$ in flyback mode.

Stage $4\left[t_{3}, t_{4}\right]$ : At $t_{3}, S_{2}$ receives a turn-off gate signal, increasing its drain-source voltage of the main switches, and $S_{c l}$ receives a turn-off gate signal. At this stage, the switching devices can achieve soft switching.
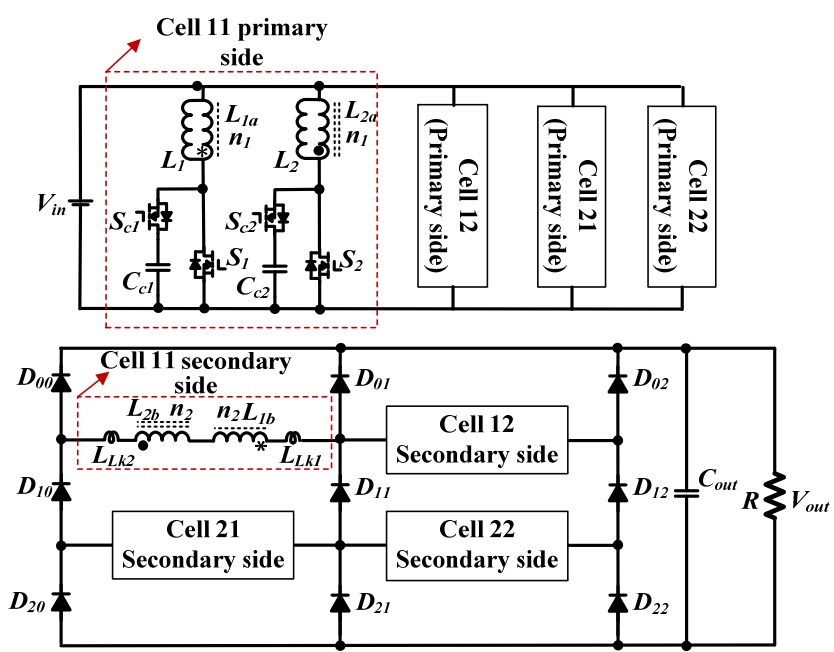

Fig. 2 A $2 \times 2$ topology.

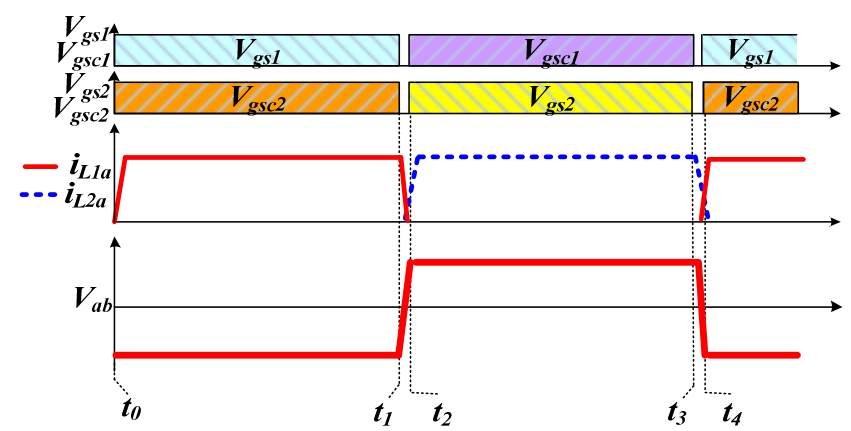

Fig. 3 Typical waveforms of a single cell.

For the $2 \times 2$ topology, there are two working modes. The first mode is presented in Fig. 4. The secondary side is divided into two groups. Group 1 consists of cells 11 and 21; group 2 consists of cells 12 and 22. Cells 11 and 21 have reverse 


\section{IEEE TRANSACTIONS ON INDUSTRIAL ELECTRONICS}

polarity by controlling the primary side of the switching devices. In order to keep the group independence, cells 11 and 12 have reverse polarity, and so do cells 21 and 22 .

In column interleaved working mode 1 (Fig. 4(a)), the secondary sides of cells 11 and 21 in group 1 are seriesconnected and the current passes through diodes $D_{01}, D_{10}$ and $D_{21}$. For group 2, the secondary sides of cells 12 and 22 are series-connected and the current flows in diodes $D_{01}, D_{12}$ and $D_{21}$. In column interleaved working mode 2 (Fig. 4(b)), the secondary sides of cells 11 and 21 in group 1 are seriesconnected and the current passes through diodes $D_{00}, D_{11}$ and $D_{20}$. For group 2, the secondary sides of cell 12 and 22 are also series-connected and the current flows in diodes $D_{02}, D_{11}$ and $D_{22}$. In the column interleaved working mode, $D_{01}, D_{11}$ and $D_{21}$ take a double current than other diodes. Besides, groups 1 and 2 have reverse polarity while cells in a group have the same polarity.

The other operational mode is the row interleaved working mode, as presented in Fig. 5. In order to keep group independence, cells $11,12,21$ and 22 have the same polarity. Their secondary sides are connected into two groups (3 and 4). Similarly, there are two row interleaved working modes. In row interleaved working mode 1 (Fig. 5(a)), for group 3, the secondary sides of cells 11 and 12 are in series connection and the current passes through diodes $D_{02}, D_{10}$ and $D_{20}$. For group 4 , the secondary sides of cells 21 and 22 are in series connection and the current flows through diodes $D_{20}, D_{12}$ and $D_{02}$. In row interleaved working mode 2 (Fig. $5(\mathrm{~b})$ ), for group 3 , the secondary sides of cells 11 and 12 are in series connection and the current passes through diodes $D_{00}, D_{12}$ and $D_{22}$. For group 4, the secondary sides of cells 21 and 22 are in series connection and the current flows through diodes $D_{00}, D_{10}$ and $D_{22}$. In the row interleaved working modes, group 1 and group 2 has the same polarity. In the same group, adjacent cells have reverse polarity. $D_{00}, D_{02}$ and $D_{20} D_{22}$ take a double current than in other diodes.

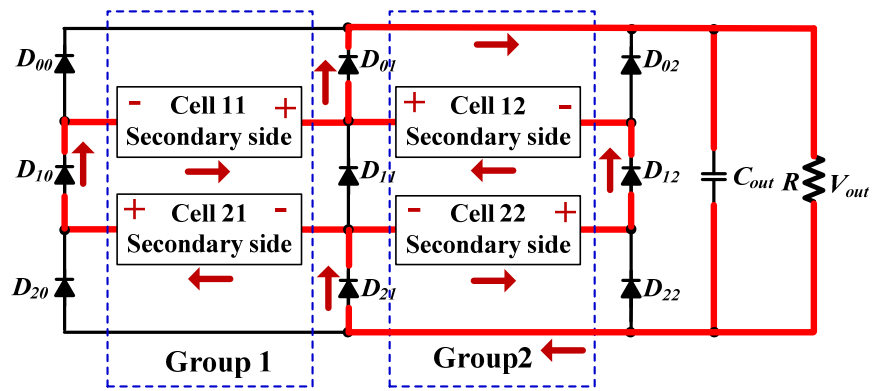

(a) Column interleaved working mode 1

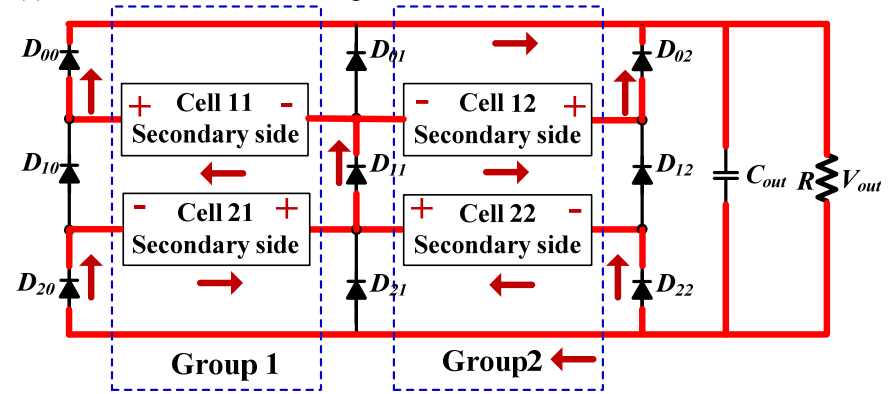

(b) Column interleaved working mode 2

Fig. 4 The $2 \times 2$ topology in the column interleaved working modes.

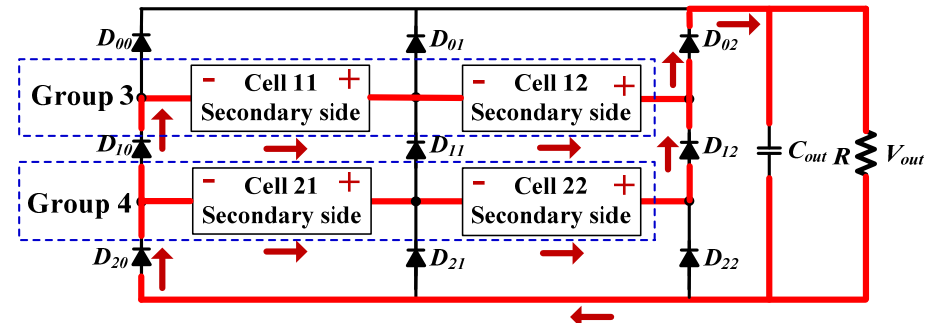

(a) Row interleaved working mode 1

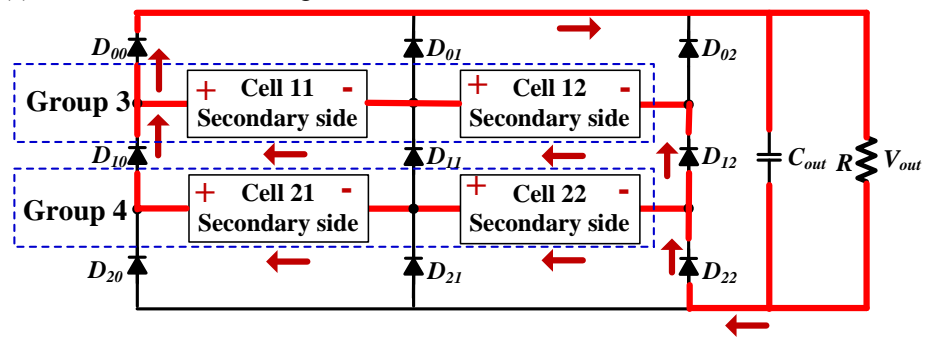

(b) Row interleaved working mode 2

Fig. 5 The $2 \times 2$ topology in the row interleaved working modes.

\section{ANAlysis OF THE $S \times P$ TOPOLOGY With COLUMN, Row, AND HYBRID WORKING MODES}

For HVDC applications, the cell matrix on the secondary side can be expanded. Similar to the working modes of the $2 \times 2$ converter, the $s \times p$ converter also has two basic working modes. Fig. 6(a) presents the column-interleaved working mode, where cells $11 \sim s 1$ are connected in series to form column group 1, and so do groups $2 \sim p$. Fig. 6(b) shows the row-interleaved working mode, where cells $11 \sim 1 p$ are connected in series to form row group 1, and so do groups $2 \sim S$. These groups all work in interleaved modes.

For a single cell, the output voltage can be expressed as

$$
\frac{\mathrm{V}_{\text {oell }}}{\mathrm{V}_{\text {in }}}=\frac{\mathrm{N}}{1-\mathrm{D}}
$$

where $D$ is the duty ratio of the main switch and $V_{\text {cell }}$ is the output voltage of a cell, $N$ is the turns ratio $\left(=n_{2} / n_{1}\right)$.

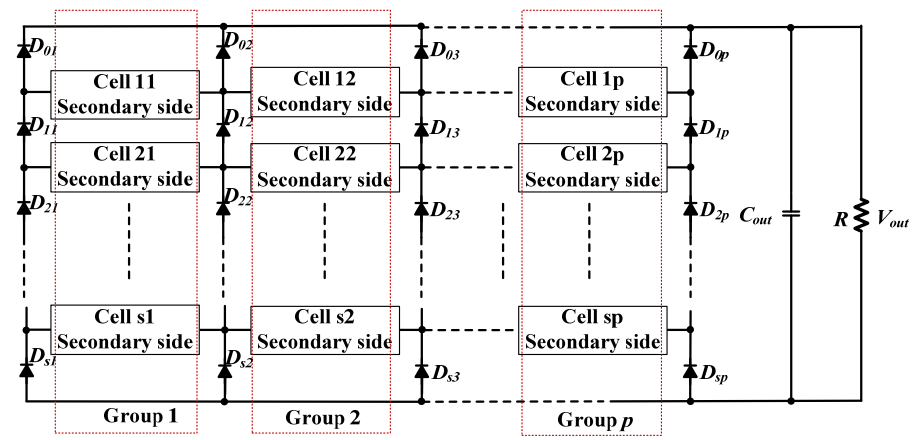

(a) Column interleaved working mode 
IEEE TRANSACTIONS ON INDUSTRIAL ELECTRONICS

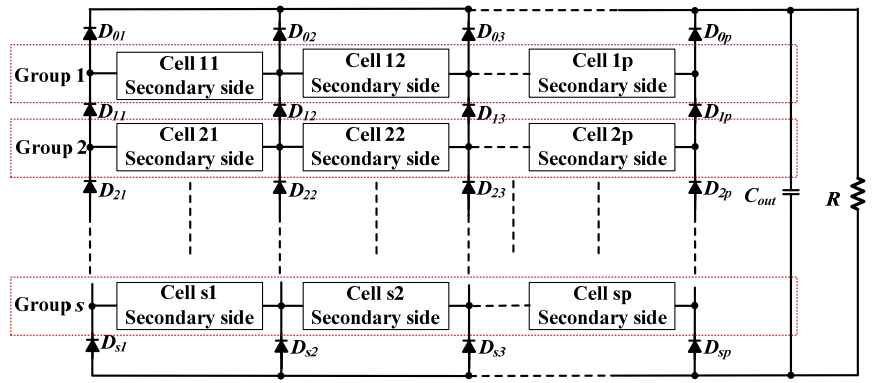

(b) Row interleaved working mode

Fig. 6 The working modes of the $s \times p$ topology.

For the column interleaved working mode, there are $s$ cells in series connection in each group and $p$ groups in parallel connection. All the cells have the same duty ratio. The output voltage can be expressed as:

$$
\mathrm{V}_{\text {out }}=\frac{\mathrm{s} \cdot \mathrm{N}}{1-\mathrm{D}} \mathrm{V}_{\text {in }}
$$

where $V_{\text {out }}$ is the output voltage of the converter.

For the row interleaved working mode, there are $p$ cells in series connection in each group and $s$ groups in parallel connection. All the cells have the same duty ratio. The output voltage is given by:

$$
\mathrm{V}_{\text {out }}=\frac{\mathrm{p} \cdot \mathrm{N}}{1-\mathrm{D}} \mathrm{V}_{\text {in }}
$$

In addition to two basic working modes, there exists a hybrid working mode. As shown in Fig. 7, there are two columns in a group. For example, all the cells in group 1 work in series connection that can increase the output voltage. The cells in each row have the same polarity, and these in adjacent rows have reverse polarity in the group. The corresponding converter output voltage can be expressed as

$$
\mathrm{V}_{\text {out }}=\frac{\mathrm{x} \cdot \mathrm{s} \cdot \mathrm{N}}{1-\mathrm{D}} \mathrm{V}_{\text {in }}
$$

where $x$ is the number of columns in the group.

In order to achieve flexibility, the working mode of idle cells is also developed. Taking the column interleaved working mode for example. Cells $11,12, \ldots, 1 \mathrm{p}$ are idle, as shown in Fig. 8(a). In each group, there are enly $s-1$ cells in working conditions, which can be employed to control the output voltage. Therefore, the number of working cells can be flexibly controlled to meet the terminal voltage requirement. Idle cells provide redundancy in the group for fault tolerant operation. In addition to the redundant cells in the group, some redundant groups are also needed to meet the different power levels, as shown in Fig. 8(b).

The output capacitor is a key component for converter design. While a large capacitance could decrease voltage ripple, it can also generate a large fault current when a short circuit occurs. Therefore, a low capacitance is favored in this work to decrease system cost and over-current amplitude. In the proposed converter, an interleaved working strategy is introduced. Groups 1 and 2 work in complementary manner to form group 12. Similarly, groups 3 and 4 form group 34, as shown in Fig. 9. Idle groups are inserted between working groups, for example, idle group 1 is inserted between groups 12 and 34 to stop the interference. Accordingly, a phase shift between groups 12 and 34 can be applied to decrease output voltage ripple. The same principle can be applied to other groups.

From Eqs. 1-4, the voltage gain can be regulated by controlling the duty ratio and the number of working cells. The relationship between voltage gain and duty ratio is given by:

$$
\mathrm{G}^{\prime}=\frac{\mathrm{T} \cdot \mathrm{N}}{(1-\mathrm{D})^{2}}
$$

where $T$ is the number of working cells in each group.

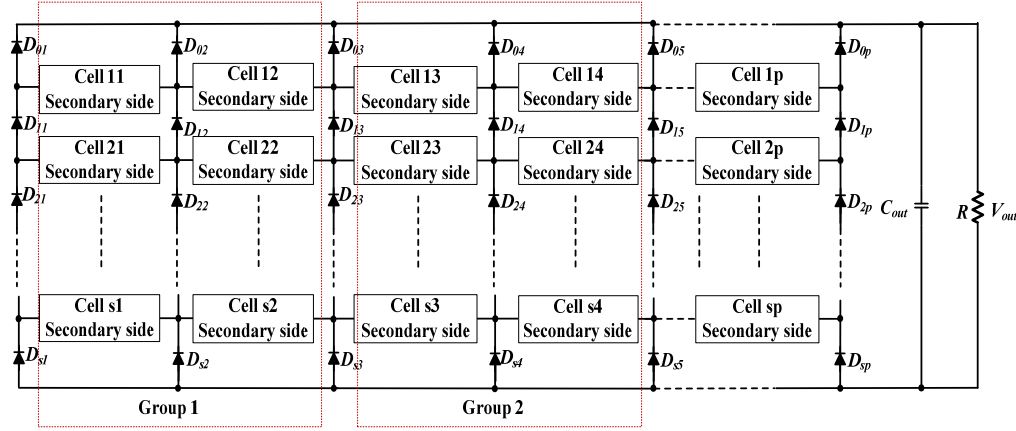

Fig. 7 Hybrid working mode.

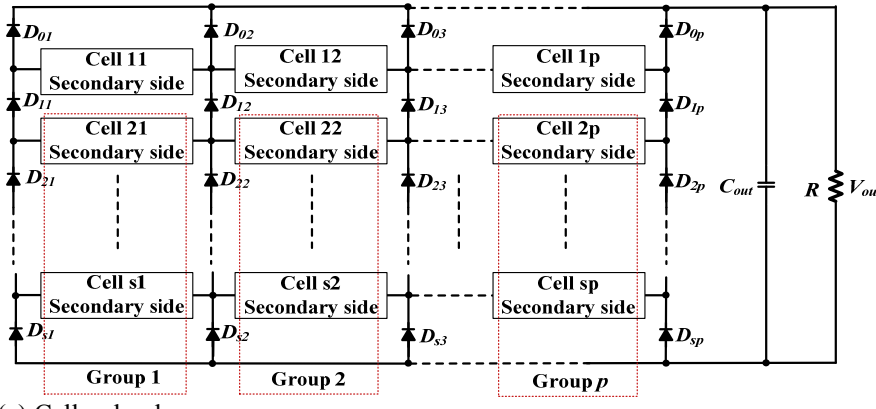

(a) Cell redundancy

Fig. 8 Redundancy strategy of the proposed converter.

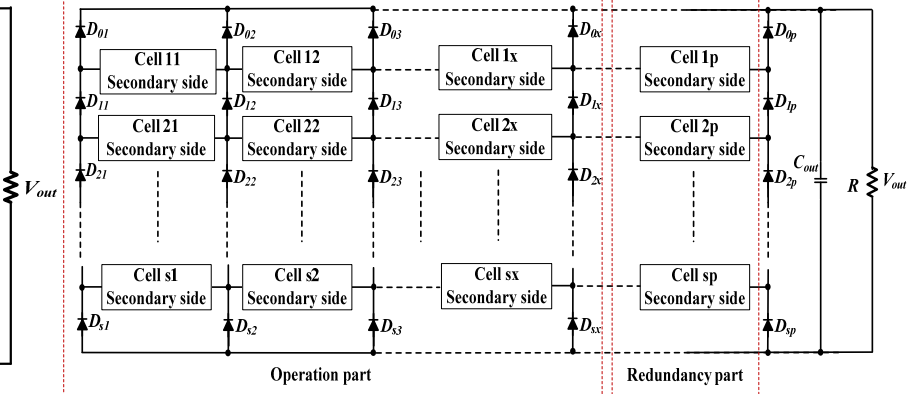

(b) Group redundancy 
IEEE TRANSACTIONS ON INDUSTRIAL ELECTRONICS

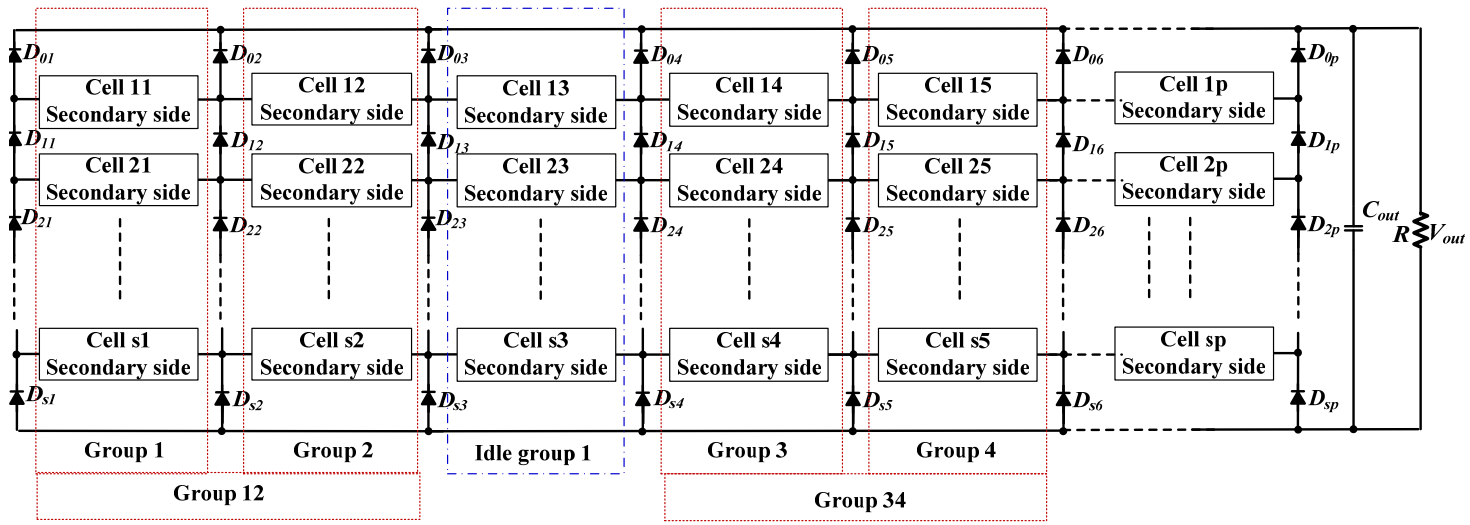

Fig. 9 Interleaved working mode of the proposed converter.

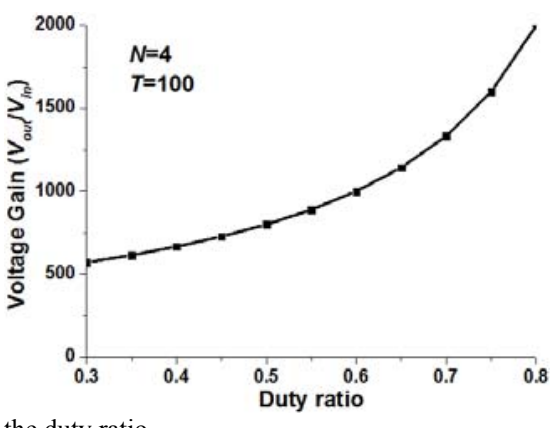

(a) Controlling the duty ratio

Fig. 10 Achievement of a high voltage gain.

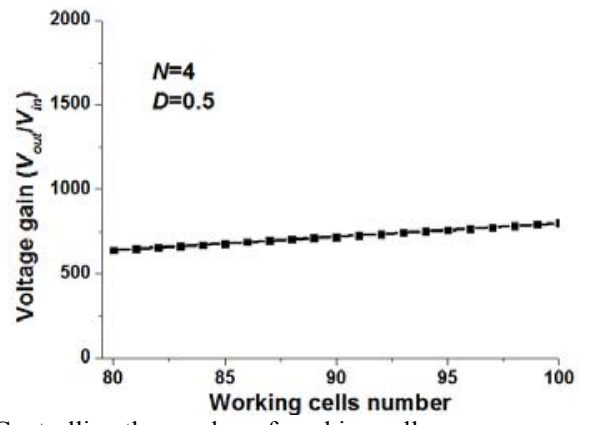

(b) Controlling the number of working cells

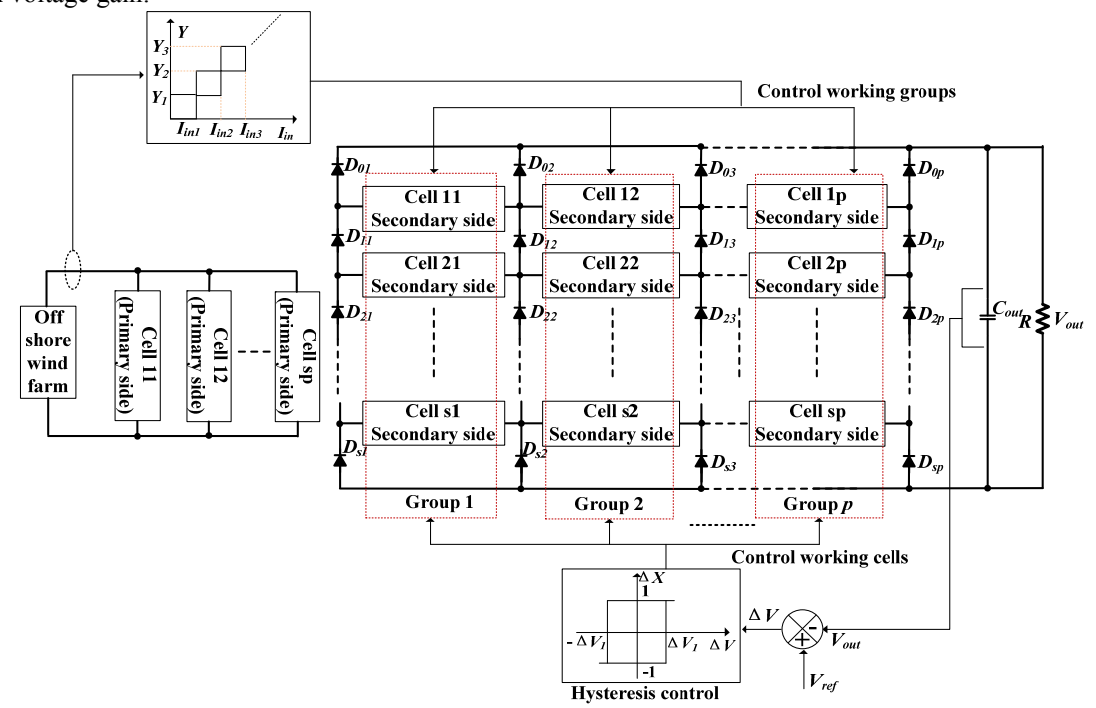

Fig. 11 Control strategy of the proposed topology in a column interleaved mode.

Fig. 10 presents the voltage gain as a function of the duty ratio and the number of working cells. It can be seen that the voltage gain increases with the duty ratio and working cells. However, the duty ratio cannot be employed as the main control variable due to the stability issue. Compared with the duty ratio control, the cell number control has a linear output characteristic and thus is employed as the control parameter.

Because all groups are connected in parallel, controlling the group numbers can vary power levels. A high number of working groups will give a higher power output. Clearly, variable voltage and power output can be achieved, as shown in Fig. 11. Voltage control is mandatory to meet the system operation requirement and power control is aimed to improve the energy efficiency. The former is achieved by controlling the number of working cells while the latter by choosing working groups according to the input current. The same idea can be applied to both row interleaved working mode and hybrid working mode.

\section{Analysis of Voltage Stress on Power DeVices}

For further analysis, the following assumptions are made: a) the two coupled inductors are identical; b) the two clamp capacitors are identical; c) the voltage of the clamp capacitors is constant; d) the effect of the dead time between the main switches and clamp switches is neglected. 


\section{IEEE TRANSACTIONS ON INDUSTRIAL ELECTRONICS}

For primary-side components, the voltage stress on main switching devices and active clamp switching devices voltage stress can be expressed as

$$
\mathrm{V}_{\mathrm{C}}=\mathrm{V}_{\mathrm{ds}}=\frac{\mathrm{V}_{\text {in }}}{1-\mathrm{D}}
$$

where $V_{d s}$ is the voltage of main switching devices and active clamp switching devices; $V_{c}$ is the voltage of the clamp capacitor.

In order to realize soft switching, the energy stored in the leakage inductance of coupled inductors should be greater than that stored in the parasitic capacitance of main switching devices when the clamp switching devices turn off. This is the condition to achieve zero voltage switching (ZVS) for main switching devices. In this case, light load operation is avoided by controlling the number of working groups, as illustrated in Fig. 11. Because the anti-parallel diode in the clamp switching device conducts prior to its turn-on signal, soft switching of clamp switches can be achieved automatically.

For secondary-side components, the rectifier diodes are of two types. One is the terminal rectifier diodes (i.e. $D_{00} \sim D_{0 p}$ and $D_{s I} \sim D_{s p}$ ). Because one winding is linked with those diodes, the corresponding voltage stress is given by

$$
V_{D 1}=\frac{N}{1-D} V_{\text {in }}
$$

Other rectifier diodes are linked with two cells. The corresponding voltage stress can be expressed as

$$
V_{D 2}=\frac{2 N}{1-D} V_{\text {in }}
$$

Clearly, all the switching devices are subjected to a low voltage stress.

\section{FAult TOlerance of THE CONVERTER}

Power switches are the vulnerable components in the converter. If primary-side switching devices are faulted, the secondary side can also be affected. In the proposed converter, the faulty cells are replaced by redundant cells in the faulty group. If the faulty cells are more than redundant cells, the duty ratio of cells in the faulty group can be employed as a control parameter.

On secondary side, when the rectifier diodes are shorted or open circuited, the proposed topology is also fault tolerant. Assume that $D_{12}$ is short-circuited in Fig. 12. In order to block the faulty element, cells 21 and 22 are made idle. The corresponding working modes are illustrated in Fig. 12. By the fault tolerance control strategy, groups 1 and 2 can still operate with faults.

Assume that $D_{12}$ is open-circuited in Fig. 13. Groups 1 and 2 are combined into one group to block the faulty element. The corresponding working modes are illustrated in Fig. 13.

Owing to the high switching frequency and interleaved structure of the secondary-side circuit, smaller filter capacitors can be used and the energy stored in them. When a DC short circuit fault occurs at the HVDC cable, the energy releasing to the cable is limited. Furthermore, the secondary side of the converter is formed by high frequency transformer windings and diodes. By turning off the primary side switching devices, the energy flow in the high-frequency transformer is terminated. Therefore, the proposed topology is characterized with a low-inertia, which assists in the fault ride-through feature of the HVDC system.

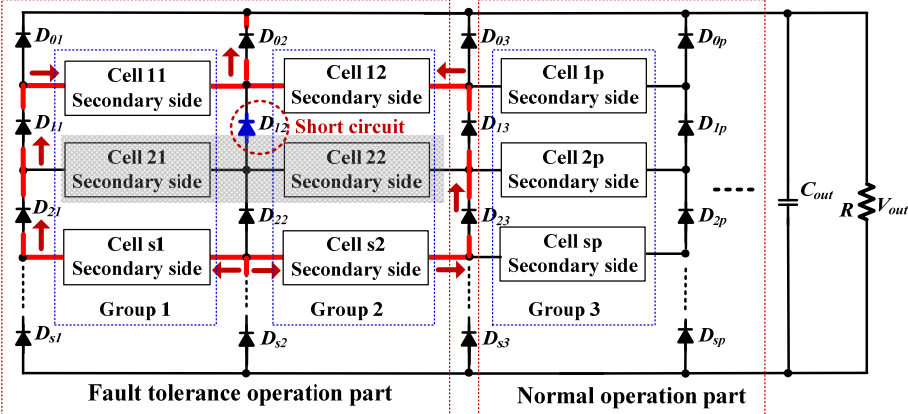

(a) Column interleaved working mode

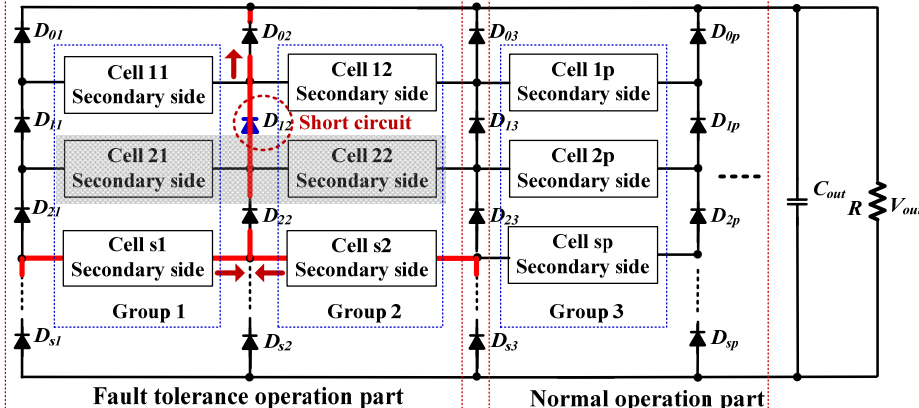

(b) Row interleaved working mode

Fig. 12 Fault tolerant operation under a diode short-circuit condition.

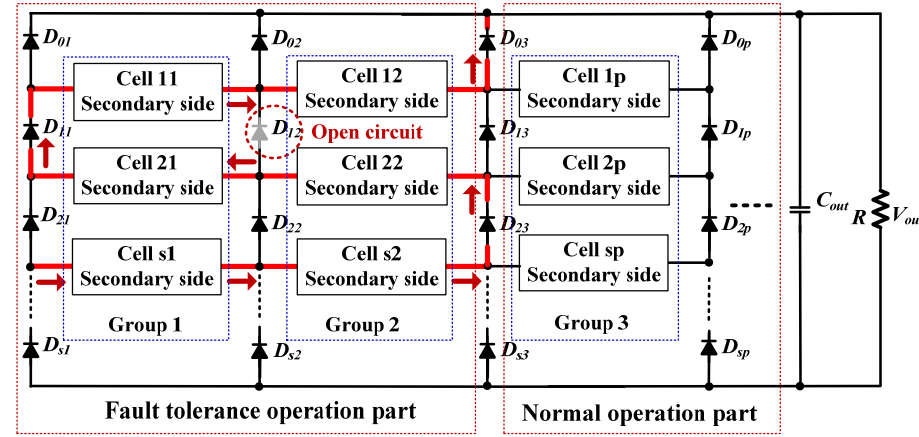

(a) Column interleaved working mode

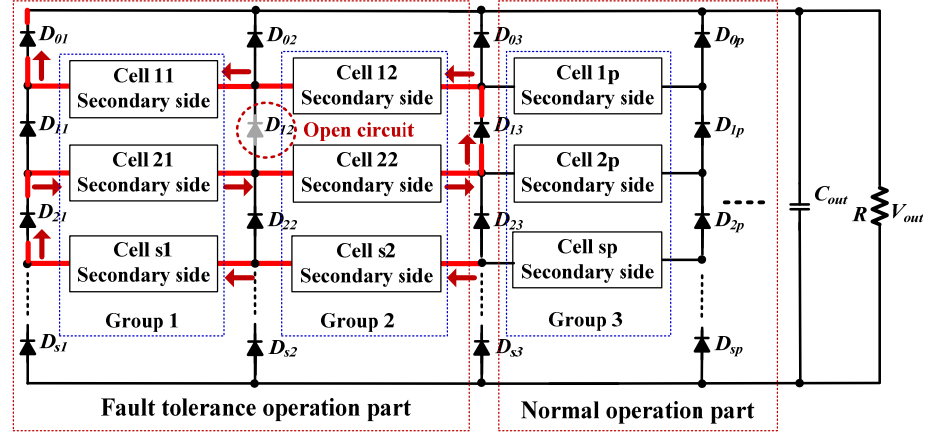

(b) Row interleaved working mode

Fig. 13 Fault tolerant operation under a diode open-circuit condition.

\section{Simulation StUdy}

A $7 \times 5$ matrix converter model is built in PSIM, using the parameters tabulated in Table I. The secondary-side structure includes one idle column and one idle row as redundancy, as presented in Fig. 14. 


\section{IEEE TRANSACTIONS ON INDUSTRIAL ELECTRONICS}

TABLE I

SIMULATION PARAMETERS OF THE CONVERTER

\begin{tabular}{l|c}
\multicolumn{1}{c}{ Component } & Value \\
\hline Cells number & 35 \\
\hline Secondary-side row number & 7 \\
\hline Secondary-side column number & 5 \\
\hline Idle row number & 1 \\
\hline Idle column number & $15 \mathrm{~V}$ \\
\hline Input voltage & $700 \mathrm{~V}$ \\
\hline Output voltage & $20 \mu \mathrm{F}$ \\
\hline Clamp capacitor & $47 \mu \mathrm{F}$ \\
\hline Output capacitor & $4: 1$ \\
\hline Turns ratio & $5 \mathrm{kHz}$ \\
\hline Switching frequency &
\end{tabular}

Groups 1 and 2 have an $180^{\circ}$ phase shift, so do groups 4 and 5. Group 3 is an idle group. In order to decrease the output voltage ripple, groups 1 and 4 have a $90^{\circ}$ phase shift. The phase relationship between the four groups is: $0^{\circ}$ for group 1 , $90^{\circ}$ for group $4,180^{\circ}$ for group $2,270^{\circ}$ for group 5. $I_{g l}, I_{g 2}, I_{g 3}$, $I_{g 4}, I_{g 5}$, and $I_{g 6}$ are the diode bridge arm currents in Fig. 14.

Fig. 15 shows the simulation results of the proposed topology working in the column-interleaved mode. The output voltage is $700 \mathrm{~V}$, as shown in Fig. 15(a). Due to the leakage inductance of the coupled inductor, the output voltage is slightly lower the theoretical calculation. Although the output capacitor is only $47 \mu \mathrm{F}$, the output voltage ripple is effectively limited by the interleaved structure. $V_{11}, V_{12}, V_{14}$ and $V_{15}$ are the output voltages of cells $11,12,14$ and 15 , respectively, which have a $90^{\circ}$ phase shift. Soft switching is achieved for main switching devices. Fig. 15(b) illustrates the voltage and current waveforms for the secondary-side diodes. The voltage stress on $D_{01}$ is half of that on other diodes $\left(D_{11}, D_{21}, D_{31}\right) . I_{g 2}$ is the sum of currents in groups 1 and 2. $I_{g 5}$ is the sum of currents in groups 4 and 5. Therefore, $I_{g 2}$ and $I_{g 5}$ have a peak current twice as much as $I_{g l}, I_{g 3}, I_{g 4}$ and $I_{g 6}$. Fig. $15(\mathrm{c})$ presents the output waveforms for cells and active clamp switches. The soft switching of active clamp switches can also be achieved.

Fig. 16 presents the simulation results of the converter under diode fault conditions. The steady state waveforms are illustrated in Fig. 16 (a). When $D_{22}$ is short-circuited at $0.0045 \mathrm{~s}$, cells 31 and 32 stop working to block the fault. Redundant cells 71 and 72 start to work (fault-tolerant operation). The dynamic response of the secondary side circuit is illustrated in Fig. 16(b). After rearranging working cells, the group output current can be recovered.

If $D_{22}$ is open-circuited at $0.005 \mathrm{~s}$, groups 1 and 2 are combined, cells $11,12,21,22,31$ and 32 are activated, and the remaining cells are made idle, according to the proposed fault tolerance strategy. Fig. 16(c) shows the corresponding simulation results. The dynamic response of the secondary side circuit is illustrated in Fig. 16(d). After rearranging working cells, groups 1 and 2 form a new group, and $I_{g 2}$ decreases to zero.

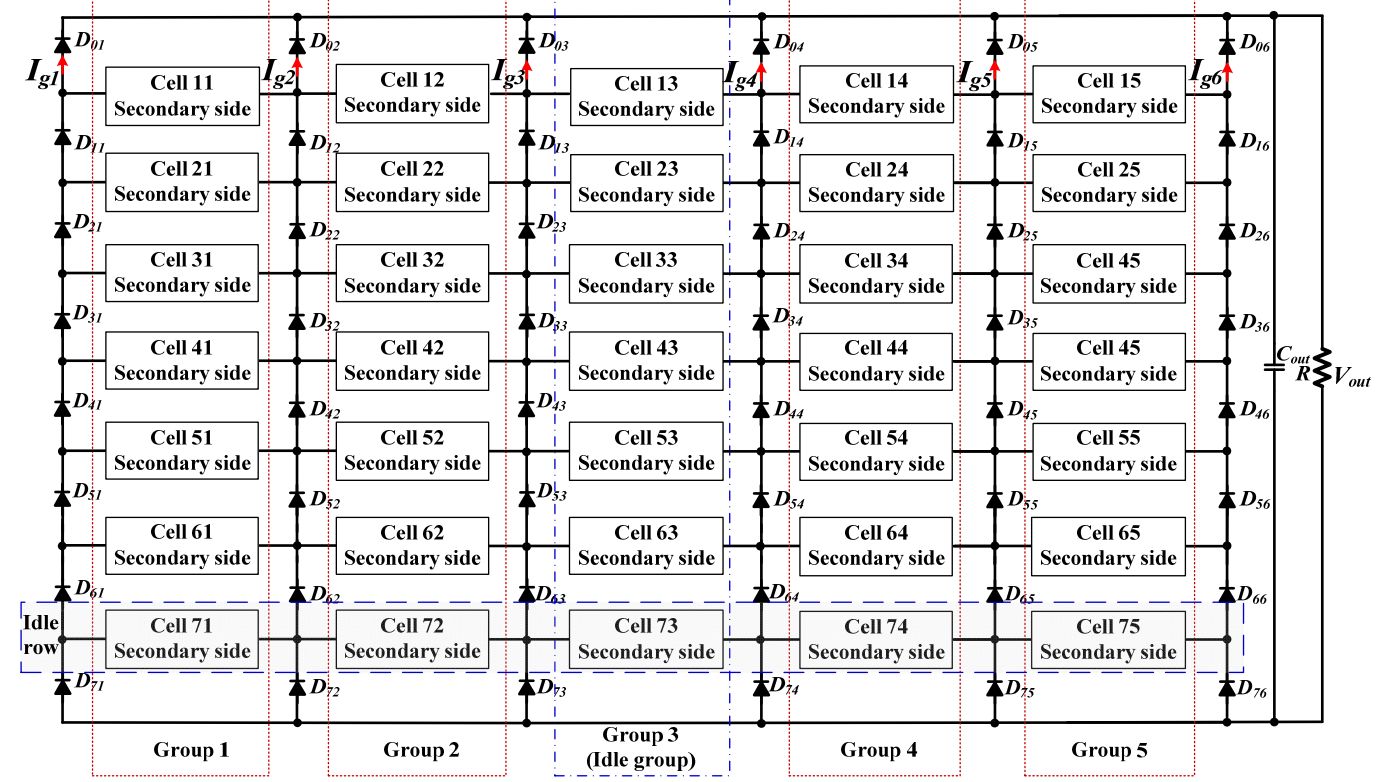

Fig. 14 The $7 \times 5$ matrix converter for simulation. 
IEEE TRANSACTIONS ON INDUSTRIAL ELECTRONICS
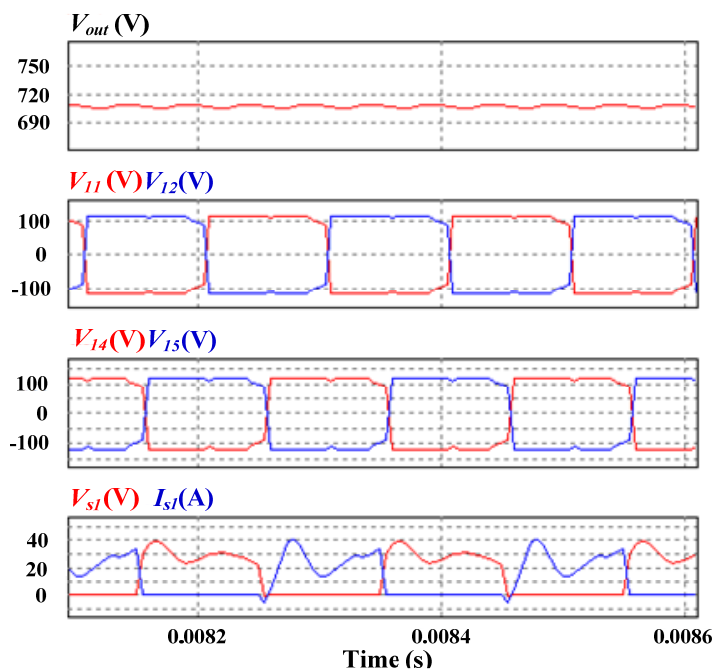

(a) Output of cells and switching devices

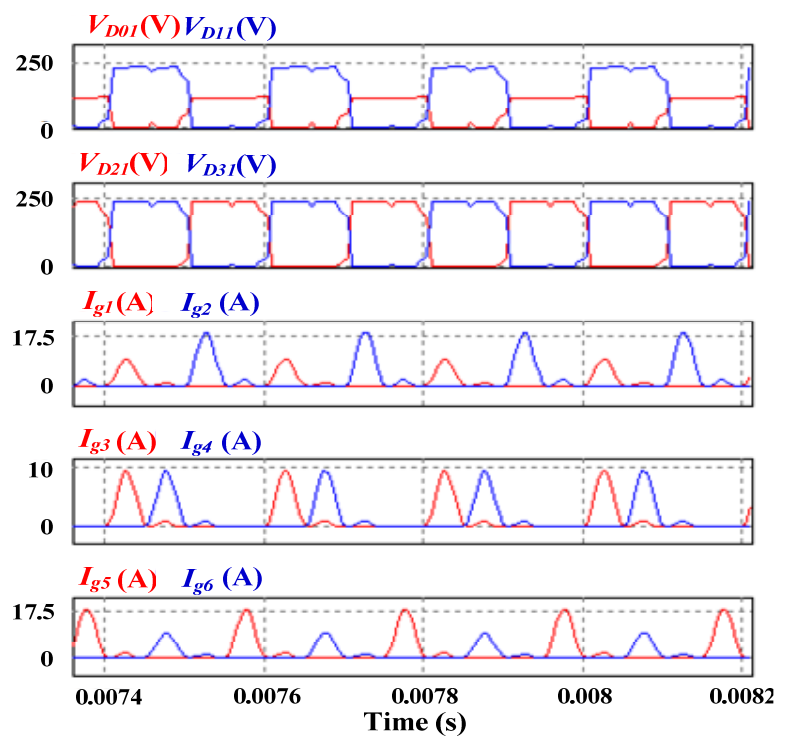

(b) Secondary diode voltage and diode bridge current

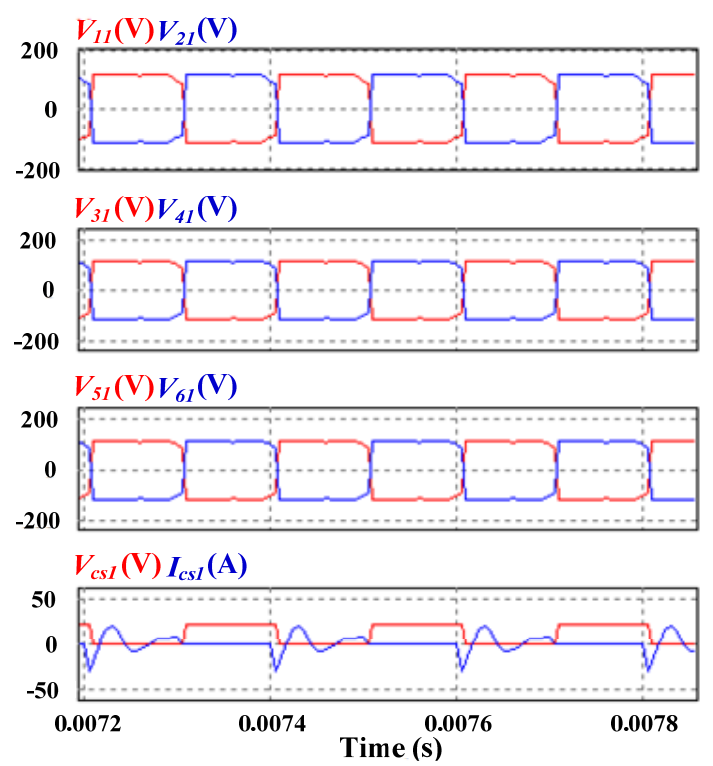

(c) Cell output

Time (s)

Fig. 15 Healthy operation of the $7 \times 5$ matrix converter.
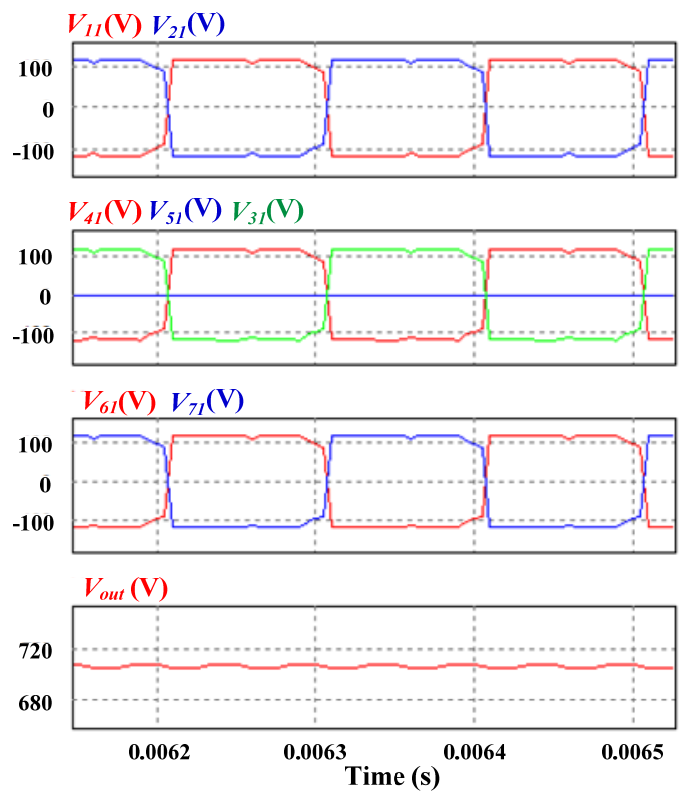

(a) Secondary-side response upon a diode short-circuit fault

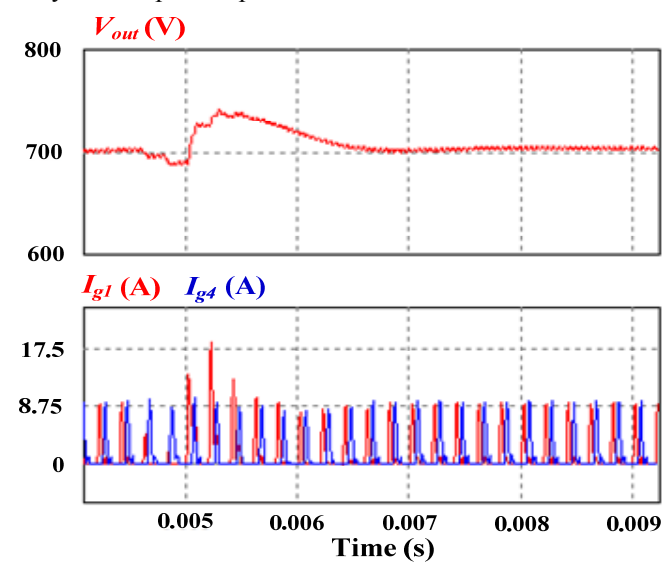

(b) Dynamic response upon a diode short-circuit fault
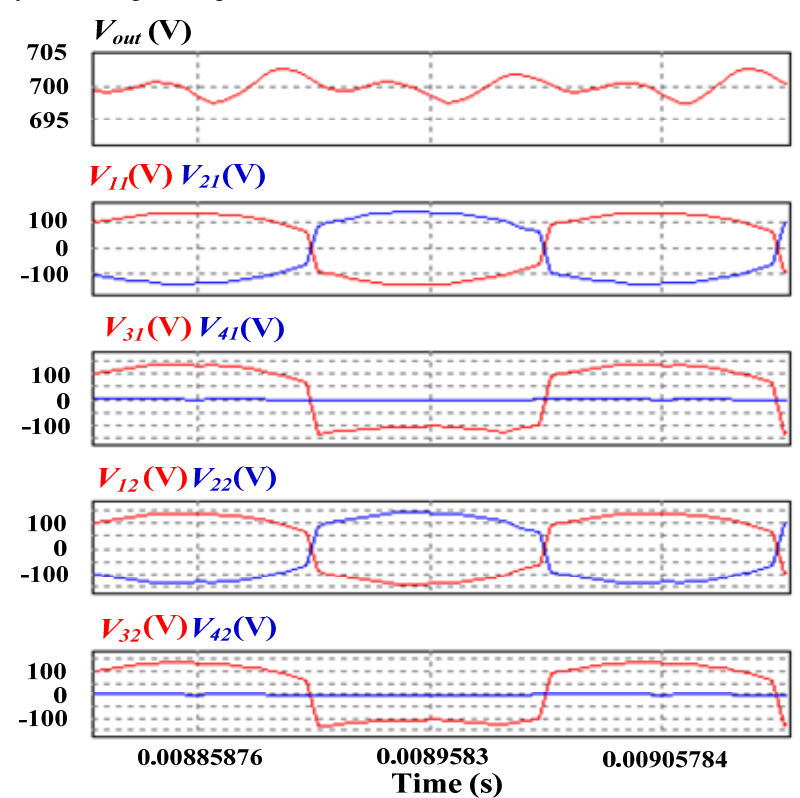

(c) Secondary-side response upon a diode open-circuit fault 
IEEE TRANSACTIONS ON INDUSTRIAL ELECTRONICS

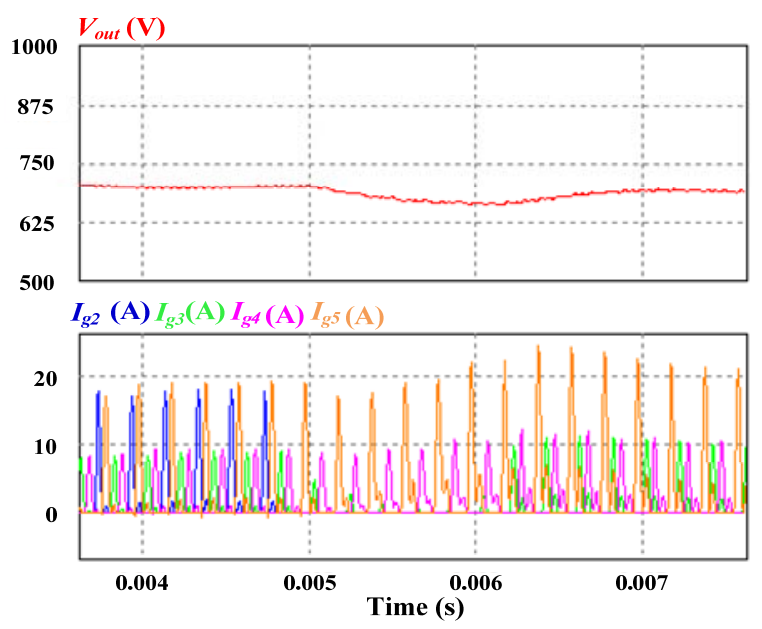

(d) Dynamic response upon a diode open-circuit fault

Fig. 16 Secondary-side fault-tolerant operation.

\section{EXPERIMENTAL VALIDATION}

A 400-W prototype converter with four cells is built up to verify the proposed topology and control strategy, as shown in Fig. 17. For this system, the input voltage is $8 \mathrm{~V}$ and output voltage is $50 \mathrm{~V}$. The main switching devices and active clamp switching devices are FDP047AN with a switching frequency of $20 \mathrm{kHz}$. Secondary-side diodes use STTH6012W, the clamp capacitor is $10 \mu \mathrm{F}$, output capacitor is $470 \mu \mathrm{F}$, and the turns ratio of coupled inductors is 4 .

The experimental results are presented in Fig. 18. The output waveforms of the four cells in column interleaved working mode are shown in Fig. 18(a). The voltage spike of each cell is caused by the dead-time effect. The currents of cells 12 and 22 are illustrated in Fig. 18(b). There is a $180^{\circ}$ phase shift between cells 12 and 22. Fig. 18(c) presents the voltage stress on diodes. Fig. 18(d) presents the voltage stress on the switching devices. From the theoretical analysis, the terminal rectifier diodes $\left(D_{00}, D_{20}\right)$ have a half voltage of other diodes $\left(D_{10}\right)$. Owing to the leakage inductance of the coupled inductor, the reverse recovery effect is decreased, as shown in Fig. 18(e). The soft switching performance is presented in Fig. 18(f).

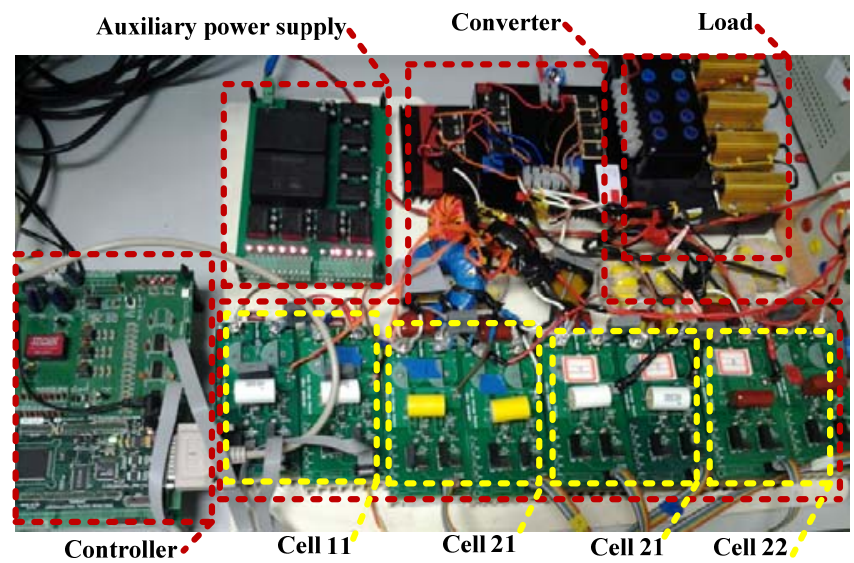

Fig. 17 Experimental platform.

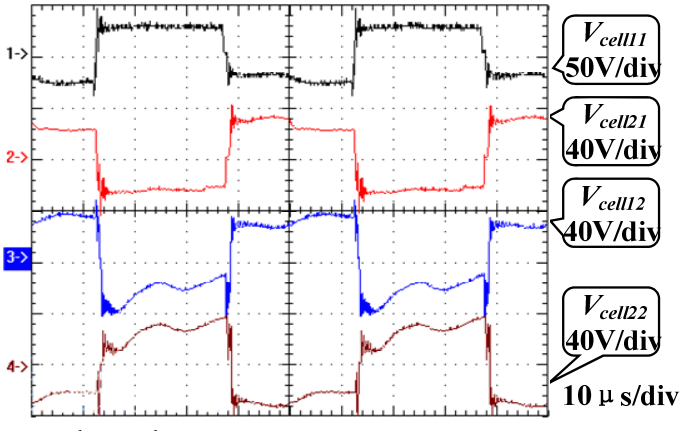

(a) Cell secondary voltage

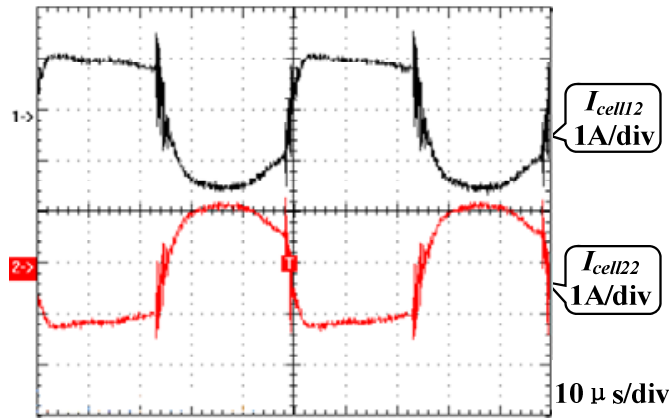

(b) Cell secondary current

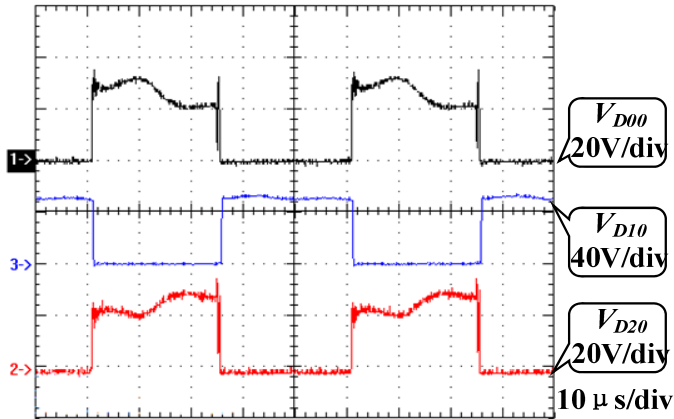

(c) Diode voltage stress

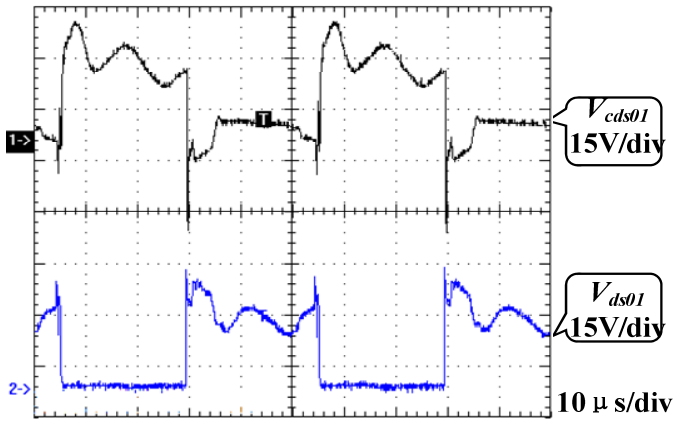

(d) Switch voltage stress

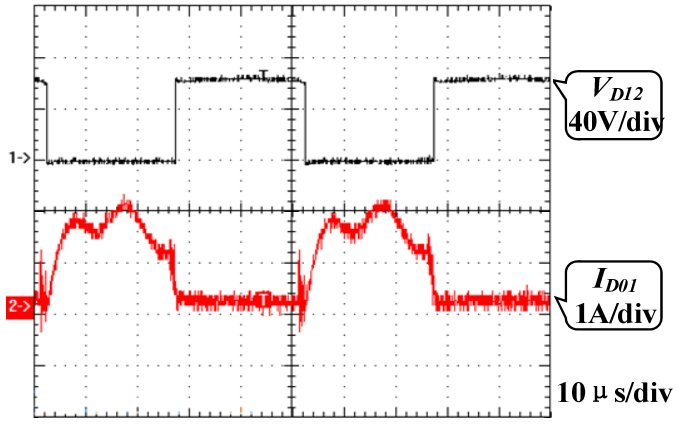

(e) Diode voltage and current 
IEEE TRANSACTIONS ON INDUSTRIAL ELECTRONICS

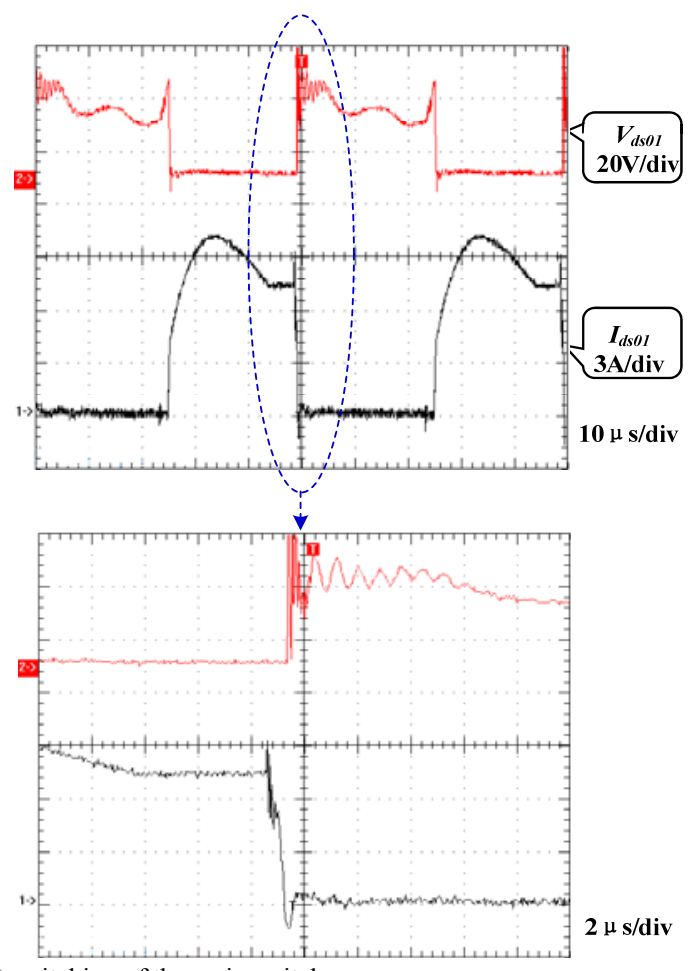

(f) Soft switching of the main switch

Fig. 18 Experimental results of the converter in column-interleaved mode.

Fig. 19 shows the experimental results of fault tolerance operation. When cell 12 is faulted, cells 11 and 21 can still operate to sustain the output voltage; and cell 22 is idle. The corresponding experimental results are shown in Fig. 19(a). Fig. 19(b) presents the primary side current of cell 11. Due to the series connection of the secondary side circuit, the current sharing on the primary side can be achieved automatically. When $D_{12}$ is open-circuited, cells $11,12,21$ and 22 work in serial connection mode to realize fault tolerant operation. The experimental waveforms are presented in Fig. 19(c). In this case, diodes $D_{02}, D_{12}$ and $D_{22}$ do not conduct. Fig. 19(d) shows the fault tolerance operation when $D_{11}$ is short-circuited. The voltage spark of $D_{12}$ is caused by dead-time effect.

Fig. 20 shows the converter efficiency under the column interleaved mode, row interleaved mode and single group conditions. When the output power is $352 \mathrm{~W}$ in the row interleaved mode, the proposed converter achieves the maximum efficiency (92\%). The row interleaved mode and column interleaved mode have a slightly lower efficiency in the low output power area while the single mode has a higher efficiency. Therefore, in low-power conditions, the use of idle mode can improve the converter efficiency. However, the main purpose of this work is to validate the effectiveness of the proposed technology by experiments on a small-scale prototype. The converter efficiency can be further improved as the power rating is increased to the target HVDC applications.

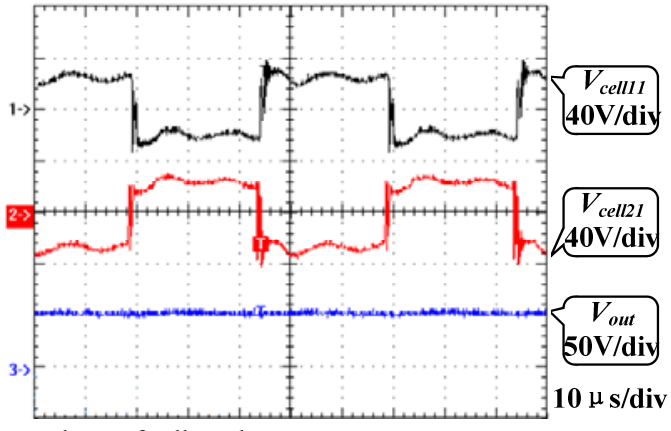

(a) Output voltage of cells and converter

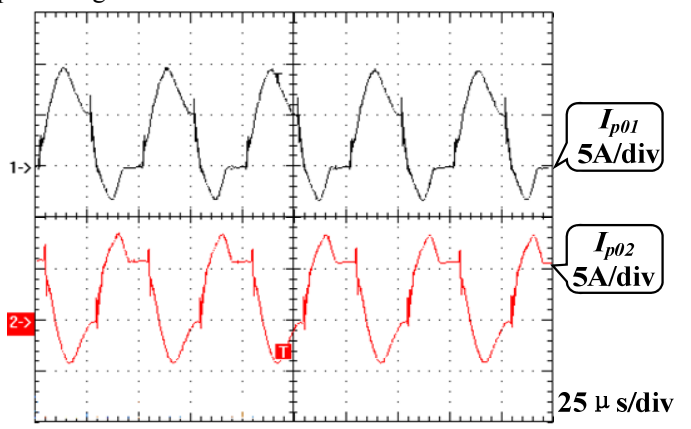

(b) Primary winding current

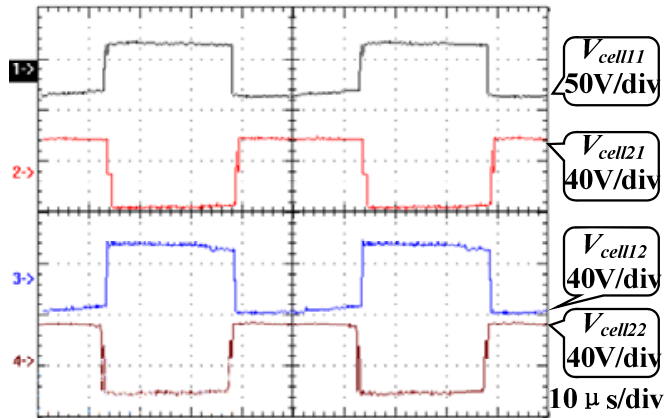

(c) $D_{12}$ open-circuit fault

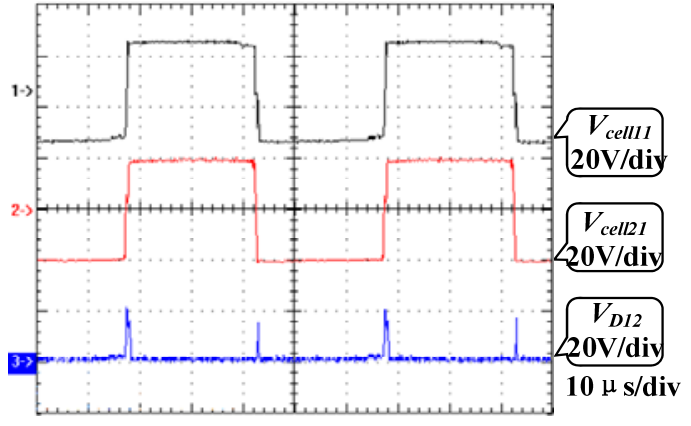

(d) $D_{11}$ short-circuit fault

Fig. 19 Fault tolerant operation of the proposed converter. 
IEEE TRANSACTIONS ON INDUSTRIAL ELECTRONICS

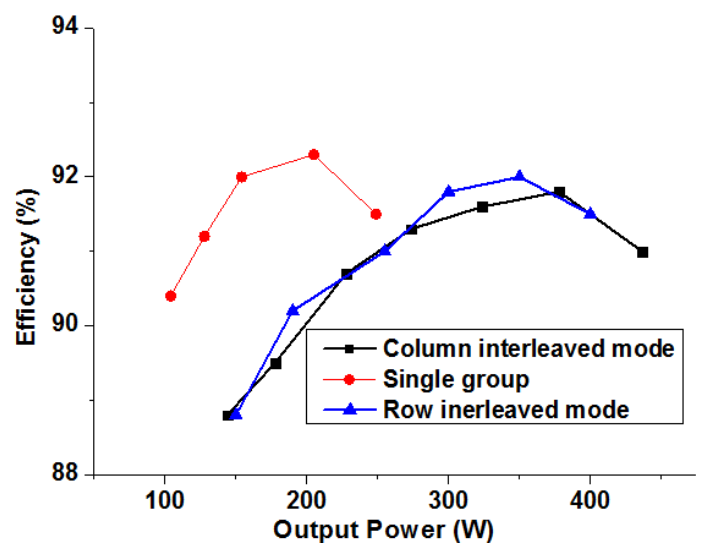

Fig. 20 Efficiency of the proposed converter.

\section{CONCLUSION}

This paper has presented a modular high step-up DC-DC converter for HVDC transmission of offshore wind power. Owing to the matrix structure on the secondary-side circuit, high power and high voltage can be built up using low-voltage switching devices. The coordinated control strategies including fault tolerance control are also proposed to take advantage of the proposed converter. From the theoretical analysis, simulation and experimental tests, the proposed converter is proven to be effective. The key features of the proposed converter are summarized as follows:

i) It has modular structure, electrical isolation, ultra high voltage step-up ability, low voltage stress on solid state devices, fault tolerant operation over a wide input power range.

ii) The increase in the row cell number can build up the converter power and the increase in the column cell number can build up the voltage level. This shows excellent scalability.

iii) Various control strategies are also developed to achieve maximum efficiency output and fault tolerant operation when subjected to short-circuit or open-circuit faults.

The proposed topology is viable for unidirectional power flow that can be used to connect wind farms with HVDC terminals. In the multi-terminal HVDC system, the grid-side converter needs bidirectional power flow, which can be achieved by conventional MMCs or AAC topologies.

\section{REFERENCES}

[1] R. E. Torres-Olguin, M. Molinas, and T. Undeland, "Offshore wind farm grid integration by VSC technology with LCC-based HVDC transmission," IEEE Trans. Sustainable Energy., vol. 3, no. 4, pp. 899907, Oct. 2012.

[2] C. Meyer, M. Hoing, A. Peterson, and R. W. De Doncker, "Control and design of DC grids for offshore wind farms,", IEEE Trans. Ind. Appl., vol. 43, no.6, pp. 1475-1482, Nov./Dec. 2007.

[3] M. Liserre, R. Cardenas, M. Molinas, and J. Rodriguez, "Overview of multi-MW wind turbines and wind parks," IEEE Trans. Ind. Electron., vol. 58, no. 4, pp. 1081-1095, Apr. 2011.

[4] L. Hanchao and S. Jian, "Voltage stability and control of offshore wind farms with AC collection and HVDC transmission," IEEE Journal of Emerging and Selected Topics in Power Electronics, vol. 2, no. 4, pp. 1181-1189, Dec. 2014

[5] R. E. Torres-Olguin, A. Garces, M. Molinas, and T. Undeland, "Integration of offshore wind farm using a hybrid HVDC transmission composed by the PWM current-source converter and line-commutated converter," IEEE Trans. Energy Convers., vol. 28, no. 1, pp. 125-134, Mar. 2013.
[6] H. Ergun, D. Van Hertem, and R. Belmans, "Transmission system topology optimization for large-scale offshore wind integration," IEEE Trans. Sustainable Energy, vol. 3, no. 4, pp. 908-917, Oct. 2012.

[7] N. Flourentzou, V. G. Agelidis, and G. D. Demetriades, "VSC-based HVDC power transmission systems: an overview," IEEE Trans. Ind. Appl., vol. 24, no. 3, pp. 592-602, Mar. 2009.

[8] T. H. Nguyen, D. C. Lee, C. K. Kim, "A series-connected topology of a diode rectifier and a voltage-source converter for an HVDC transmission System," IEEE Trans. Power Electronics, vol. 29, no. 4, pp. 1579-1584, Apr. 2014.

[9] L. Xu, L. Yao, and C. Sasse, "Grid integration of large DFIG-based wind farms using VSC transmission," IEEE Trans. Power Sys., vol. 22, no. 3, pp. 976-984, Aug. 2007

[10] A. Egea-Alvarez, F. Bianchi, A. Junyent-Ferre, G. Gross, and O. GomisBellmunt, "Voltage control of multiterminal VSC-HVDC transmission systems for offshore wind power plants: design and implementation in a scaled platform," IEEE Trans. Ind. Electron., vol. 60, no. 6, pp. 23812391, Jun. 2013.

[11] J. Liang, T. Jing, O. Gomis-Bellmunt, J. Ekanayake, and N. Jenkins, "Operation and control of multiterminal HVDC transmission for offshore wind farms," IEEE Trans. Power Del., vol. 26, no. 4, pp. 2596-2604, Oct. 2011.

[12] S. M. Muyeen, R. Takahashi, and J. Tamura, "Operation and control of HVDC-connected offshore wind farm," IEEE Trans. Sustainable Energy., vol. 1, no. 1, pp. 30-37, Apr. 2010.

[13] P. Bresesti, W. L. Kling, R. L. Hendriks, and R. Vailati, "HVDC connection of offshore wind farms to the transmission system," IEEE Trans. Energy Convers., vol. 22, no. 1, pp. 37-43, Mar. 2007.

[14] S. Kenzelmann, A. Rufer, D. Dujic, F. Canales, and Y. R. de Novaes, "Isolated DC/DC structure based on modular multilevel converter," IEEE Trans. Power Electron., vol. 30, no. 1, pp. 89- 98, Jan. 2015.

[15] X. Li, Q. Song, W. Liu, H. Rao, S. Xu, and L. Li, "Protection of nonpermanent faults on DC overhead lines in MMC-based HVDC systems," IEEE Trans. Power Del., vol. 28, no. 1, pp. 483-490, Jan. 2013.

[16] I. A. Gowaid, G. P. Adam, A. M. Massoud, S. Ahmed, D. Holliday, and B. W. Williams, "Quasi two-level operation of modular multilevel converter for use in a high-power DC transformer with DC fault isolation capability," IEEE Trans. Power Electron., vol. 30, no. 1, pp. 108-123, Jan. 2015.

[17] X. Zhang, T. C. Green, and A. Junyent-Ferre, "The modular multilevel converter for high step-up ratio DC-DC conversion," IEEE Trans. Ind. Electron., vol. 62, no. 8, pp. 4925-4936, Aug. 2015.

[18] D. Montesinos-Miracle, M. Massot-Campos, J. Bergas-Jane, S. GalceranArellano, and A. Rufer, "Design and control of a modular multilevel DC/DC converter for regenerative applications," IEEE Trans. Power Electron., vol. 28, no. 8, pp. 3970- 3979, Aug. 2013.

[19] T. Luth, M. M. C. Merlin, T. C. Green, F. Hassan, C. D. Barker, "Highfrequency operation of a DC/AC/DC system for HVDC applications," IEEE Trans. Power Electron., vol. 29, no. 8, pp. 4107- 4115, Aug. 2014.

[20] S. P. Engel, M. Stieneker, N. Soltau, S. Rabiee, H. Stagge, and R. W. De Doncker, "Comparison of the modular multilevel DC converter and the dual-active bridge converter for power conversion in HVDC and MVDC grids," IEEE Trans. Power Electron., vol. 30, no. 1, pp. 644-656, Feb. 2015.

[21] M. Hajian, J. Robinson, D. Jovcic, and B. Wu, " 30 kW, 200 V/900 V, thyristor LCL DC/DC converter laboratory prototype design and testing," IEEE Trans. Power Electron., vol. 29, no. 3, pp. 1094-1102, Mar. 2014.

[22] J. A. Ferreira, "The multilevel modular DC converter," IEEE Trans. Power Electron., vol. 28, no. 10, pp. 4460- 4465, Oct. 2013.

[23] G. J. Kish, M. Ranjram, P.W. Lehn, "A modular multilevel DC/DC converter with fault blocking capability for HVDC interconnects," IEEE Trans. Power Electron., vol. 30, no. 1, pp. 148-162, Jan. 2015.

[24] A. Parastar and J. K. Seok, "High-gain resonant switched-capacitor cellbased DC/DC converter for offshore wind energy systems," IEEE Trans. Power Electron., vol. 30, no. 2, pp. 644-656, Feb. 2015.

[25] J. Robinson, D. Jovcic, and G. Joos, "Analysis and design of an offshore wind farm using a MV DC grid," IEEE Trans. Power Del., vol. 25, no. 4, pp. 2164-2173, Oct. 2010

[26] N. Denniston, A. Massoud, S. Ahmed, and P. Enjeti, "Multiple-module high-gain high-voltage DC-DC transformers for offshore wind energy systems," IEEE Trans. Ind. Electron., vol. 58, no. 5, pp. 1877-1886, May 2011.

[27] W. Chen, A. Q. Huang, C. Li, G. Wang, and W. Gu, "Analysis and comparison of medium voltage high power DC/DC converters for 


\section{IEEE TRANSACTIONS ON INDUSTRIAL ELECTRONICS}

offshore wind energy systems," IEEE Trans. Power Electron., vol. 28, no. 4, pp. 2014-2023, Apr. 2013.

[28] T. Lequeu, G. Kalvelage, and P. Aubin, "An innovating topology of power converter: serial and parallel auto regulated configuration (SPARC)," IEEE Trans. Ind. Appl., vol. 40, no. 2, pp. 592-602, Mar/Apr 2004.

[29] J. Wang, T. Zhao, J. Li, A. Q. Huang, R. Callanan, F. Husna, A. Agarwal, "Characterization, modeling, and application of 10-kV SiC MOSFET," IEEE Trans. Electron Devices, vol. 55, no. 8, pp. 1798-1806, Jul. 2008.

[30] W. Li, L. Fan, Y. Zhao, X. He, D. Xu, and B. Wu, "High-step-up and high-efficiency fuel-cell power-generation system with active-clamp flyback-forward converter," IEEE Trans. Ind. Electron., vol. 59, no. 1, pp. 599-610, Jan. 2012

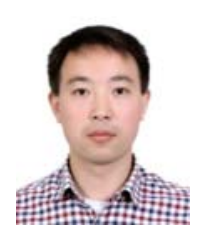

Yihua Hu (SM'15) received the B.S. degree in electrical motor drives in 2003, and the Ph.D. degree in power electronics and drives in 2011, both from China University of Mining and Technology, Jiangsu, China. Between 2011 and 2013, he was with the College of Electrical Engineering, Zhejiang University as a Postdoctoral Fellow. Between November 2012 and February 2013, he was an academic visiting scholar with the School of Electrical and Electronic Engineering, Newcastle University, Newcastle upon Tyne, UK. He is currently a research associate with the Department of Electronic \& Electrical Engineering, University of Strathclyde, Glasgow, UK. His research interests include PV generation system, power electronics converters \& control, and electrical motor drives.

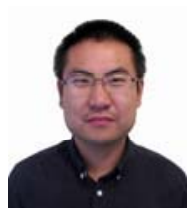

Rong Zeng (S'10) received the B.Sc. degree and M.Sc degree in electrical engineering from Hunan University, Changsha, China in 2008 and Zhejiang University, Hangzhou, China, in 2011, respectively.

Since 2012, he has been working toward the Ph.D degree in the Department of Electronic \& Electrical Engineering, University of Strathclyde, Glasgow, UK. His research interest includes high power converters for HVDC application and grid integration of renewable energy systems.

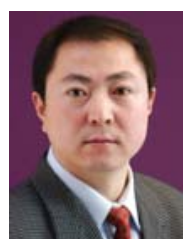

Wenping Cao (SM'11) received the B.Eng in electrical engineering from Beijing Jiaotong University, Beijing, China, in 1991, and the Ph.D. degree in electrical machines and drives from the University of Nottingham, Nottingham, U.K., in 2004.

$\mathrm{He}$ is currently a Marie Curie Fellow with the Department of Electrical Engineering and Computer Science, Massachusetts Institute of Technology, Cambridge, MA, U.S.A. and a Chair Professor of Electrical Power Engineering with Aston University, Birmingham, U.K. His research interests include fault analysis and condition monitoring of electric machines and power electronics.

Prof. Cao was the recipient of the Best Paper Award at the 2013 International Symposium on Linear Drives for Industry Applications (LDIA), the Innovator of the Year Award from Newcastle University, Newcastle upon Tyne, U.K., in 2013, and the Dragon's Den Competition Award from Queen's University Belfast in 2014. He serves as an Associate Editor for IEEE Transactions on Industry Applications, IEEE Industry Applications Magazine and IET Power Electronics; he is also the Chief Editor for three Special Issues and one book, and an Editor for Electric Power Components and Systems Journal as well as nine other International Journals. Prof. Cao is also a Member of the Institution of Engineering and Technology (IET) and a Fellow of Higher Education Academy (HEA).

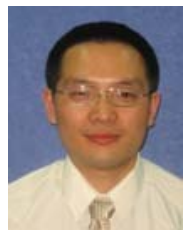

Jiangfeng Zhang obtained his $\mathrm{BSc}$ and $\mathrm{PhD}$ in computing mathematics and applied software from Xi'an Jiaotong University, China, in July 1995 and December 1999 , respectively. He is a senior lecturer at the Department of Electronic and Electrical Engineering, University of Strathclyde. He is also a member of the IFAC TC6.3 (Power and Energy Systems). His research interests include optimization modelling and control of energy systems, with a focus on energy efficiency and demand side management.

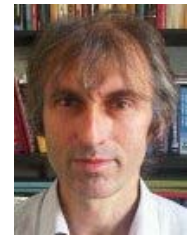

Stephen J. Finney received the M.Eng. degree from Loughborough University of Technology, Loughborough, U.K., in 1988 and the Ph.D. degree from Heriot-Watt University, Edinburgh, U.K., in 1995.

For two years, he was with the Electricity Council Research Centre laboratories near Chester, U.K. He is currently a Professor with the University of Strathclyde, Glasgow, U.K. His areas of research interest are HVDC, $\mathrm{MMC}$, renewable generation, and electrical vehicle. 